\title{
Trajetórias de jovens em situação de vulnerabilidade social: sobre a realidade juvenil, violência intersubjetiva e políticas para jovens em Porto Alegre - RS
}

\author{
GARLOS A. GADEA", JOSÉ SILON", FÁTIMA S. DA ROSA*, \\ MÁRCIA DA S. GEZAR", HILÁRIO DICK"
}

\section{Resumo}

O artigo tem por objetivos introduzir algumas reflexões acerca do significado contemporâneo do termo juventude, bem como realizar ponderações importantes em torno ao binômio juventude-violência. Quer-se, igualmente, apresentar alguns dados relevantes para compreender a situação de vulnerabilidade concreta de jovens que residem em certos bairros da cidade de Porto Alegre, na medida em que permitem deduzir as fortes relações entre violência, educação e família. Por último, o interesse recai em realizar uma breve crítica dos três principais paradigmas sobre políticas para jovens (em torno ao trabalho, à educação e ao esporte) que classicamente se têm implementado. No contexto dessas reflexões, sugere-se considerar de importância o desenvolvimento de uma "cultura digital" e seu coadjuvante "capital social" para a eventual formulação de uma "nova" política para jovens que vivem em situação de vulnerabilidade social em contextos urbanos.

Palavras-chave: Jovens. Vulnerabilidade social. Violência. Política para juventude.

* Universidade do Vale do Rio dos Sinos (UNISINOS), Brasil. 


\title{
Trajectories of disadvantaged young people: on youth's reality, interpersonal violence, and public policies for young people in the city of Porto Alegre - RS
}

\begin{abstract}
This article aims to introduce some reflections on the contemporary meaning of the term youth, and present important considerations on the pair youth-violence. It seeks, also, to introduce some relevant data that help to understand the particular vulnerability of young people who live in certain neighborhoods in the city of Porto Alegre, since these data enable to infer strong relationships between violence, education and family. Finally, it outlines a critical review of the three main paradigms of public policies for juveniles (related to work, education and sports) that have been traditionally implemented. In the context of these reflections it is important to consider the development of a "digital culture" and its side effect, the "social capital", for the formulation of a "new" policy for young people living under social vulnerability in urban contexts.
\end{abstract}

Keywords: Juveniles. Social Vulnerability. Violence. Youth policies. 


\section{Introdução}

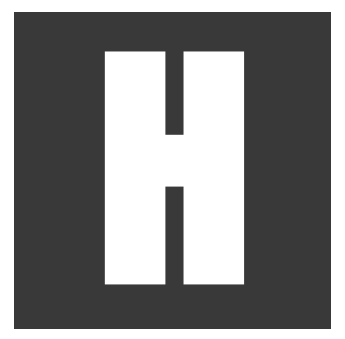

á algum tempo assiste-se ao crescimento de pesquisas que relacionam a violência com o segmento jovem da população'. Nelas, evidencia-se a alta vulnerabilidade dos jovens residentes nos denominados "bairros problemáticos" 2 das grandes cidades brasileiras. A incerteza de muitos jovens quanto ao futuro assim como a falta de políticas de inclusão social eficientes parece traduzir-se em aumento das transgressões entre aqueles que residem, fundamentalmente, nos "bairros populares", e protagonizam pequenos furtos e assaltos à mão armada, envolvem-se com o tráfico de drogas ou realizam certos atos de depredação urbana (Adorno, 1999; Koury, 2004). Por outro lado, outras pesquisas têm apontado um caráter mais "racializado" da violência entre os jovens, ao assinalar a estreita relação entre violência, pobreza e racismo (Moraes; Souza, 1999; Wacquant, 2005; Soares, 1996; PNUD, 2005). O tom dessas pesquisas não tem sido, em absoluto, o de estigmatizar aquela população mais jovem como protagonista central de atos de violência e criminalidade, mas sim o de revelar a perversa relação existente entre marginalidade urbana, violência e juventude.

Os objetivos do presente texto são diversos, e tomam como ponto de partida essas constatações iniciais. Primeiramente, visa introduzir algumas reflexões acerca do significado contemporâneo de juventude, bem como do binômio juventude-violência. Logo, apresentar alguns dados considerados relevantes para compreender a situação de vulnerabilidade concreta desses jovens, na medida em que possibilita deduzir as fortes relações entre violência, educação e família. Para tal, analisar-se-ão dados

\footnotetext{
1 Ver, por exemplo, algumas das pesquisas desenvolvidas pelo Núcleo de Estudos da Violência da Universidade de São Paulo (http://www.nevusp.org/portugues/index.php). Ver também no Núcleo de Referência em Segurança Urbana (http://www.nusur.org.br/nusur/).

2 Ver o interessante artigo "A invenção de 'bairros problemáticos'" de Sylvie Tissot publicado em Le Monde Diplomatique, outubro de 2007.
} 
recentes extraídos de fontes oficiais de informação, como o IBGE, a Assessoria de Informação e Gestão da FASE-RS (Fundação de Atendimento Socioeducativo) e o Instituto Nacional de Estudos e Pesquisas Educacionais (INEP). Por último, realiza uma crítica dos três principais paradigmas de políticas para a juventude (relativas a trabalho, educação, e esporte e lazer), tradicionalmente considerados na elaboração de políticas para jovens. No contexto dessas reflexões, sugere-se considerar a importância que podem assumir o "capital social" e a "cultura digital" nos momentos de se pensarem iniciativas públicas para a heterogênea população jovem.

Esses objetivos inserem-se no espaço geográfico e social de quatro bairros que exibem altos índices de vulnerabilidade social em Porto Alegre (Restinga, Rubem Berta, Santa Teresa e Lomba do Pinheiro), com problemas ligados a baixa escolaridade, violência, além das problemáticas de um frágil mercado de trabalho. As reflexões a seguir são resultado da inter-relação dos dados empíricos pesquisados com a realidade desses bairros e as sociabilidades juvenis nelas existentes.

\section{Acerca da(s) juventude(s)}

O campo da sociologia da juventude desenvolveu-se a partir de duas perspectivas analíticas fundamentais. Por um lado, aquela que procurava definir e compreender as características convergentes da juventude como categoria social generalizável, aplicável a diferentes contextos e situações. Por outro lado, uma perspectiva que tendia a enfatizar as características divergentes, configurando as diversas juventudes como grupos culturais autônomos, e aderindo à sentença da existência de múltiplas juventudes, pois esta seria uma noção definida com relação a contextos e situações particulares. Muitos pesquisadores e agentes políticos, confrontados com os atuais processos sociais de transformação do mercado de trabalho, do 
sistema de ensino e das dinâmicas familiares, têm apontado, também, a necessidade de se observar o que representa o "prolongamento da juventude" como fase de vida ${ }^{3}$, que se tem derivado na chamada "geração suspensa". Não obstante, esta ideia, frequentemente associada às dificuldades próprias da transição à vida adulta, parte de pressupostos um tanto questionáveis: aquele de que os jovens querem ser adultos de forma compulsiva e, por outro lado, aquele que considera possível "objetivar", com dados e eventos identificáveis, a transição etária. Esses pressupostos se deslegitimam num cenário de acentuada singularização de trajetórias e comportamentos juvenis, desencadeando a eliminação das fronteiras simbólicas da juventude como grupo específico.

A representação da juventude como fase da vida também é questionada a partir das novas mudanças sociais e econômicas, afetando todos os grupos etários e, especialmente, as novas gerações. Estas têm sido confrontadas, de maneira particular, com a erosão de certos marcos de referências culturais, especialmente aqueles ligados aos mecanismos de socialização e transição para a vida adulta. As referências culturais que serviam como fios condutores das condutas e das trajetórias individuais se têm enfraquecido sensivelmente: as transformações no mercado de trabalho (flexibilização, precarização e imprevisibilidade), nas estruturas familiares (pluralização das formas de organização familiar, o crescimento dos divórcios, etc.) e as novas dinâmicas associadas ao consumo são exemplos disso. Esses fatos parecem ter pressionado os jovens atuais a criarem novos estilos de vida e elaborar novas identidades, numa multiplicidade de opções disponíveis ou criadas. Claro está que as "escolhas racionais" realizadas pelos jovens não podem ser consideradas fundamentos centrais da sua vida social, já que a vida coletiva supõe, antes de tudo, limitações

\footnotetext{
3 Por exemplo, ao prolongar a estadia na casa dos pais, retardando a assunção plena do estatuto de adulto. Isso se pode constatar ao analisar a constituição de lares e/ou as características das "unidades domésticas estendidas" (Ver Tabela 2).
} 
estruturais (econômicas, políticas, normativas). De fato, "ação" e "estrutura", e a maneira como ambas se articulam nas sociedades atuais, devem ser consideradas no momento da análise das sociabilidades juvenis contemporâneas. Assim, as trajetórias juvenis devem ser contempladas como um processo de individualização estruturada sob os condicionamentos e limitações impostos pela vida coletiva.

Um eventual exemplo dos "poderes de coerção" social contemporâneo, que impera sob a lógica da sedução, é a mídia. A roteirização dos programas de TV, dos jornais diários e da publicidade é orientada por expectativas construídas pelo mundo adulto sobre o que seria importante para os jovens. Nesse universo representacional, os jovens "adquirem corpo" nas adjetivações que, em muitas ocasiões, misturam elementos negativos, estigmatizações e construções identitárias com evidente tom discriminatório. Assim, os meios de comunicação parecem apresentar duas opções possíveis para a construção simbólica do que seria "ser jovem": por um lado, uma imagem ancorada no universo da moda, da publicidade e do consumo; por outro, uma representação ligada à violência e à delinquência, ao consumo de drogas e à eventual estridência de determinados estilos musicais. No primeiro caso, assiste-se a uma espécie de "colonização da mídia" dos estilos estéticos e expressivos juvenis pelo sistema da moda e do marketing, em correspondência à noção de consumismo impulsionado pela indústria cultural (Featherstone, 1995). No segundo caso, assiste-se a um movimento generalizado em que a mídia constrói um retrato da juventude associado ao "perigo urbano", à violência e à insegurança.

Entretanto, o olhar sobre a juventude contemporânea não pode recair nessas simplificações interpretativas, e muito menos em manipulação oportunista dos meios de comunicação. As sociedades contemporâneas são demasiado diferenciadas e policontextuais e, portanto, as expe- 
riências dos jovens devem ser analisadas a partir de múltiplas filiações identitárias correspondentes a necessidades e negociações contínuas no seu cotidiano. Múltiplos mundos sociais desenham múltiplas experiências sobre o ser jovem. Daí que a singularização das experiências de vida dos jovens remete à especificidade de contextos e às múltiplas oportunidades e estratégias elaboradas para o melhor convívio social, chamando a atenção para os processos de mudança nas sociabilidades e nas formas que essas começam a adquirir. Consequentemente: qual seria o "olhar" privilegiado para análise da experiência social e das formas das sociabilidades da juventude na atualidade? Estaria no consumo e no mercado da moda, no universo de estilos estéticos, ou na generalizada ideia da "insegurança urbana", em que se podem aglutinar os fundamentos principais para a compreensão do fenômeno da sociabilidade juvenil em contextos de vulnerabilidade social?

Como resultado das novas tensões, frustrações, ansiedade e contradições da juventude contemporânea, começa a esboçar-se uma sociabilidade marcada por uma tipificação nova: a neotribalização (Maffesoli, 1989). Durante o anos 1980 e 1990, passou-se a perceber que a neotribalização respondia a um fenômeno complexo, de crescente expressividade. Apresentava-se como resposta social e simbólica à excessiva racionalidade burocrática, ao isolamento individual urbano e à frieza de uma sociedade competitiva. Adolescentes e jovens pareciam sentir, nas tribos, a possibilidade de encontrar uma nova via de expressão, uma maneira de distanciar-se da "normalidade" que não os satisfazia e, além disso, a ocasião de intensificar suas vivências pessoais e encontrar um núcleo gratificante de afetividade. Como diria Maffesoli (1995), a sociabilidade em transição que nos sugere esse processo de neotribalização anuncia a passagem de um princípio comunicacional e simbólico individualista para um relacional, e, de forma análoga, a passagem de um princípio político para outro, de caráter estético. 
A análise das "tribos urbanas" de Michel Maffesoli contribuiu muito para uma frutífera revisão da literatura sobre o tema "juventude". No clássico trabalho $O$ tempo das tribos, preocupou-se em analisar o comportamento dos jovens urbanos na ótica do nomadismo, do consumo, dos novos formatos associativos e afetivos e da fragmentação social. $\mathrm{O}$ eixo central era demonstrar que os microgrupos emergentes de jovens tomavam a forma de comunidades emocionais nas quais o valor do afetivo, o " estar junto", a valorização do corpo e os laços de proximidade primários conduziam não mais a um princípio individualista do social mas a uma produção cultural de grande complexidade. Nesse emaranhado de sociabilidades emergentes, Maffesoli chama a atenção para o caráter efêmero desses laços associativos ou neotribais, sua fluidez e flexibilidade, a forte carga local de seu desenvolvimento e o escasso formato organizacional segundo critérios em que o fator político é um componente aglutinador privilegiado. Dessa maneira, realiza-se uma separação conceitual de grande interesse para compreender as dinâmicas de sociabilidade da juventude: por um lado, uma interação política, projetiva, racionalizada, individualista; por outro, uma identificação estética, emocional, não-direcionada, que se satisfaz em viver o dia-a-dia, no simples prazer de "viver com outros".

De forma simultânea, Gilles Lipovetsky (1994), embora não possa ser considerado um autor que analisa os comportamentos juvenis contemporâneos, traz uma série de noções sociológicas que, sem dúvida, se apoiam numa observação concreta das novas modalidades associativas e de comportamento dos jovens. Sem mencioná-los, antecipa modalidades de socialização emergentes sobre a base de uma espécie de "narcisismo coletivo": solidariedade grupal, "redes situacionais", retração dos objetivos universais. Para Lipovetsky, o atual processo de personalização que protagonizamos supõe que a última figura assumida pelo individu- 
alismo contemporâneo não resida numa "independência associal", mas em ramificações e conexões com interesses miniaturizados, hiperespecializados: grupos de jovens que realizam trabalhos voluntários diversos ou as diferentes comunidades emocionais das quais fala Maffesoli. Isso não significa um processo tendente a conduzir os indíviduos, a reduzir a carga emocional investida no espaço público ou nas "esferas transcendentais" e a aumentar as prioridades da esfera privada. A valorização do imediato, dos temas cotidianos e das preocupações existenciais de cada dia resulta ser o motor constitutivo dos novos valores emergentes nos grupos de jovens atuais.

Dos estudos de Maffesoli e, posteriormente, das análises de Lipovetsky, surgem perguntas interessantes para compreender os novos contornos das práticas culturais e das sociabilidades dos jovens atuais. Magnani (2005), por exemplo, adverte para a necessidade de reavaliar o conceito de tribo desenvolvido amplamente na literatura sobre jovens durante os anos 1980 e 1990, afirmando que uma de suas mais claras limitações está em possibilitar um mal-entendido entre o sentido atribuído ao termo "tribo" nos estudos tradicionais de etnologia e seu uso para designar grupos de jovens no cenário da metrópole. Segundo Magnani, nada está mais longe da realidade do que considerar os grupos de jovens como grupos bem definidos e delimitados, com regras e costumes particulares. Por isso, propõe substituir o termo "tribo urbana" por "cultura juvenil", uma virada interessante no marco teórico que deixa de privilegiar perspectivas antropológicas, de corte etnográfico, para dar maior ênfase aos contornos teóricos mais globais, ligados aos denominados "estudos culturais". A mudança terminológica sugere, também, uma mudança na forma de encarar a questão juvenil, "que transfere a ênfase da marginalidade para a identidade, das aparências para as estratégias, do espetacular para a vida cotidiana, da deliquência para o ócio, das imagens para os 
"atores" (idem). O que certamente pode ser constatado é que, ao falar de "tribo", o objeto juventude parece reduzir-se à "forma" da sociabilidade assumida, em que seu caráter particularmente fechado e sólido negligencia a capacidade de movimento que os comportamentos juvenis vieram assumindo. Talvez a noção de "rede" possa ser mais propícia para designar o tipo de sociabilidade empreendida pelos jovens atuais, na medida em que se faz presente o hibridismo e a contaminação de uma multiplicidade de códigos estéticos, valorativos e de consumo generalizado, bem como de experiências sociais com diversos interesses práticos.

Dessa maneira, marcadas tendências de uma autorresponsabiliza-ção sobre os destinos sociais, de uma reflexividade autonôma e de certas preocupações com a "conectividade", com os aspectos relacionais da vida social, sugerem uma cultura juvenil a meio caminho entre a "paixão" pelo contato na forma das neotribos e um processo de individualização ciente de um mundo complexo, incerto e "presenteísta". Os jovens, na atualidade, parecem desenhar ações com forte viés estratégico nas suas escolhas e decisões, sem que isso represente uma subjetividade construída sob valores associados à competitividade e ao isolamento. Muito contrariamente, nos encontramos perante uma cultura juvenil que se preocupa com seu ambiente, além de muito sensibilizada com os desafios da realidade que vivencia.

\section{A violência e os jovens}

Sabe-se que não existe um consenso absoluto acerca dos limites de idade entre uma etapa etária que supõe a adolescência e a juventude. Tampouco existe com relação aos limites do que se entende, especificamente, com o termo juventude, já que em muitas análises a faixa etária se estende até os 29 ou 30 anos. Partindo dessa consideração, o que sim 
parece ser consensual ao definir os jovens é, em geral, sua atual exposição à violência. Para muitos, esta exposição se torna ainda mais materializável como correlato a um cotidiano de vulnerabilidade social. Certamente, a falta de oportunidades de trabalho (para aqueles com mais de 18 anos), da diversificação de alternativas de lazer e de ambientes escolares incentivadores pode explicar, em parte, como as notórias carências no que respeita ao desenvolvimento educativo e cultural interferem nos atuais problemas que atravessa a juventude. Essa tem sido, reiteradamente, a explicação outorgada à maior parte dos problemas relacionados à população jovem, vinculados a iniciativas de políticas públicas abrangentes e ao voluntarismo de muitos atores políticos e sociais. Sem dúvida, muito se tem avançado a respeito, mas o medo, a exposição à violência, a insegurança, a percepção de um "futuro incerto" e a participação ativa em atos de violência continuam constituindo-se em traços identitários evidentes de uma juventude que, em muitas ocasiões, percebe-se submetida ao estigma e à exclusão social.

Ao analisar-se a relação entre violência e juventude, deve-se ter em conta as características próprias desses jovens contemporâneos: transitoriedade, disposição a assumir riscos, sociabilidades intensas e etapa de definição de identidades e papéis sociais. Às vezes, é a pobreza - as carências materiais e simbólicas que muitos bairros podem apresentar como marca estrutural - que serve como explicação fundamental para atos de violência em que possam estar envolvidos jovens, sob o risco da estigmatização social. Não obstante, e como muitos estudos demonstram, em absoluto a pobreza pode ser linearmente associada à violência urbana e, fundamentalmente, nem com a delinquência. Há uma combinação de variáveis que contemplam os níveis de exposição da população jovem à violência urbana, ligadas basicamente a problemas da socialização primária (na família) e da socialização secundária, surgidos de carências ma- 
teriais, educativas, de inserção no mercado de trabalho e de dispositivos socialmente integradores de diversas características (ligados ao lazer, ao esporte, a atividades lúdicas, etc.).

Mas, a que jovens se está fazendo referência? Evidentemente, as experiências individuais dos jovens atuais tendem a ser caracterizadas a partir de um novo panorama sociocultural. Por exemplo, a estabilidade de outrora é substituída pela incerteza com o futuro e pelo risco nas vivências cotidianas. A juventude, não se esgotando numa simples "transição" cronológica na vida individual, trata-se de uma noção que remete a particularidades nos processos de individualização, tanto com relação a valores e atitudes específicas quanto às estratégias operacionalizadas na negociação dos caminhos para a vida futura. Várias pesquisas (Abramo; Branco, 2005) têm apontado a emergência de modos reflexivos e criativos de construção biográfica, assim como a adoção de éticas de vida mais expressivas, conviviais e "hedonistas", especialmente quando referidas à importância atribuída a valores como a autonomia, a diversão e a experimentação. Nesse cenário, a violência emerge como forma de sociabilidade que denota uma linguagem ou narrativa que procura a "integração negada" ou "postergada", um desejo e interesse por visibilidade e reconhecimento. Como linguagem, a violência se nutre de uma semântica escorregadia, de difícil apreensão e compreensão. Por isso, pergunta-se com frequência: como compreender esta juventude contemporânea perante a violência urbana? Como é vivenciado por muitos jovens em situação de vulnerabilidade social um contexto cotidiano de "violência intersubjetiva"? Como a própria violência se insere no repertório cultural da construção subjetiva dos jovens de hoje?

A violência intersubjetiva não se entende, unicamente, como resultado de conflitos inerentes às relações de poder desigual entre diferentes sujeitos, mas sim como associada à vulnerabilidade e à violência de um 
determinado grupo social. A exposição à violência contínua e a participação ativa em atos violentos (como vítima ou protagonista) desenha uma forma de relação específica, em que fatores estruturais, conjunturais e institucionais atuam conjuntamente no seu aparecimento. Trata-se de um tipo de violência que atua negativamente sobre a autoestima (por exemplo, a violência doméstica) e a internalização do desprezo e do não-reconhecimento (por exemplo, na violência policial-institucional), gerando lesões significativas na ordem social e normativa. Sem dúvida, a violência é considerada um grave problema no país, constituindo-se, até os dias de hoje, na principal causa de morte de crianças e adolescentes a partir dos 05 anos de idade.

Trata-se de uma população cujos direitos básicos são muitas vezes violados, como o acesso à escola, a assistência à saúde e aos cuidados necessários para o seu desenvolvimento. As crianças e adolescentes são, ainda, exploradas sexualmente e usadas como mão-de-obra complementar para o sustento da família ou para atender ao lucro fácil de terceiros, às vezes em regime de escravidão (SBP, 2001, p.7).

A "violência intersubjetiva" deve ser compreendida no contexto de uma série de mudanças sociais recentes e de enorme significado. A violência, enquanto produzida numa ordem do conflito intersubjetivo, deve definir-se como uma "linguagem", como uma maneira de expressar carências ou desarranjos nos mecanismos diversos de integração social. Abordá-la tal qual a manifestação de um "desvio" de conduta não possibilita sua compreensão na atualidade. A violência pode ser uma forma de "falar", quando outros meios de expressão social e cultural estão ausentes. Por outro lado, a "violência intersubjetiva" denuncia as eventuais falhas na preeminência do "laço social" que mantém uma comunidade, família ou grupo humano coeso em torno a regras sociais e normas de conduta claras e evidentes aos olhos de todos. A violência intersubjetiva é 
a manifestação da ausência dos "laços sociais vinculantes", evidenciando problemas concretos nos processos socializadores primários (na família) e/ ou secundários (grupos de amigos, escola, etc.). Nesse sentido, o "ideal de comunidade", substrato de uma vida coletiva, cede espaço à reafirmação do indivíduo, constituído na fortaleza última para a sobrevivência econômica e moral na atualidade. Concretamente, a "violência intersubjetiva" juvenil está inserida num contexto social que, paulatinamente, tem adquirido os traços de uma nova exclusão social. Trata-se da incapacidade ou impossibilidade, para muitos setores da população, de inserir-se em "círculos sociais" (capital social) ou dinâmicas de sociabilidade que possam trazer autoestima e reconhecimento intersubjetivo. Essa é uma das principais razões para que muitos indivíduos sintam que seus sofrimentos se relacionam com a praticamente nula "interiorização" das regras do jogo social, numa realidade cada vez mais exigente em autorreflexividade e autonomia individual (Gadea, 2010).

Um primeiro exemplo ao qual se pode fazer referência é o da violência sexual e corporal. Percebe-se como a violência sexual e corporal (estupro, assédio sexual, ato obsceno, favorecimento à prostituição, lesão corporal, maus tratos) é, talvez, o tipo de violência que mais preocupa instituições públicas e educadores. Residem nas características dos vínculos familiares e na própria constituição familiar atual, eventuais explicações do fenômeno. A denominada "família estendida", caracterizada pela convivência de três gerações (avôs, pais, tios e filhos) sob o mesmo teto tem gerado múltiplos conflitos geracionais, precipitando situações de violência contra os mais vulneráveis. Logo, os vínculos e relações familiares (extensíveis às relações entre vizinhos) com frágeis laços afetivos e de interesses parecem possibilitar o aparecimento de uma violência "difusa" e "silenciosa", que termina gerando problemas na constituição subjetiva de crianças e adolescentes no seu processo de socialização. Trata-se de um tipo de violência que, no ge- 
ral, tem sua materialização nos bastidores de relações familiares aparentemente estáveis e "normais" aos olhos de todos.

Concomitante a isso, a estigmatização juvenil tem-se tornado moeda corrente. De fato, existem duas principais fontes de estigmatização da população jovem: via associação com o delito e via associação com o consumo de drogas. Um dos mitos mais difundidos relaciona-se à fatal associação entre "menoridade" e delinquência juvenil; algo longe da realidade. Está fartamente demonstrado no mundo que o delito protagonizado pela população jovem e menor de idade (contemplando homicídios, furto, roubo e lesão corporal) é de 8 a 10 \% do total, ou seja, o "mundo adulto" é o principal protagonista da denominada delinquência urbana nas grandes e medianas cidades do mundo ${ }^{4}$. Dessa maneira, é falsa tal associação. Por outro lado, a "criminalização das drogas", considerando-se que o consumo de maconha, por exemplo, é produto de uma juventude que lida com a ilegalidade e que conspira contra a "ordem cidadã", tem-se estabelecido como discurso estigmatizante para as sociabilidades juvenis, o lazer e a própria experiência jovem.

E o que dizer acerca de um tipo de violência que atua não só estigmatizando, mas fundamentalmente excluindo "linguagens" e dinâmicas culturais e sociais por demais importantes numa "sociedade da informação"? Faz-se referência à suposta (e falsa) concepção de uma "linguagem" (estética e comportamental) implicitamente violenta dos "jogos eletrôni$\cos ^{\prime \prime}$, frequentemente inseridos nas práticas lúdicas dos jovens. Oportuno lembrar o que já Gustave Le Bon (1952 [1895]) mostrava, em fins do século XIX: como as crenças coletivas eram cada vez mais "alucinações coletivas" cridas como certas, mas real e crescentemente induzidas por conteúdos "irracionais", ou seja, de complexa explicação prática. A teoria crítica, tempos depois, iria enfatizar coisas semelhantes, adjudicando

\footnotetext{
4 Ao pesquisar os mesmos delitos nos bairros aqui analisados, tem-se constatado o mesmo porcentual de incidência delitiva dos menores de 18 anos.
} 
poder à sedução do icônico na construção dessas alucinações tomadas como opinião pública ou senso comum. Isso se reflete não só nos discursos construídos em torno da juventude e de sua associação com o delito e o consumo de drogas, mas também no que significa associar a prática do mundo lúdico dos "jogos eletrônicos" com a eventual prática de ações violentas pelos jovens. Para muitos, ao se inserirem no universo lúdico de competições e "jogos" em que conteúdos de eventual violência são apresentados, os jovens terminariam "imitando" em suas práticas e relações cotidianas aquilo que de violento experimentam nos devaneios recreativos dos "jogos eletrônicos". Essa premissa se fundamenta na "sensação" de que os jovens, ao imitar a dinâmica violenta dos jogos, apresentam-se carentes de reflexividade, "mimetizados" pela linguagem da forma dos jogos. Mas, será que a linguagem do universo dos "jogos eletrônicos" só desenvolve capacidades de mimetismo, cópia e "irrealidade"? Ou, pelo contrário, possibilita o contato de muitos jovens, por analogia, com o mundo cotidiano e "externo" ao próprio jogo, gerando a prática de destrezas psicomotoras necessárias ao seu desenvolvimento intelectual? Não haveria grandes chances de reflexividade em tudo isso? Responder a essas interrogações pode conduzir à derrubada do falso mito da mimese entre tecnologia e ação humana. Esses tipos de associações entre a violência (de fato e em potencial) e juventude representam, simplesmente, uma mínima parcela do amplo universo representacional sobre o que significa "ser jovem" na atualidade.

\section{Os bairros e os itinerários juvenis}

Nos bairros Restinga, Lomba do Pinheiro, Rubem Berta e Santa Teresa, espaços urbanos que comportam semelhanças socioculturais e econômicas importantes, observa-se uma sociabilidade juvenil particular, e que 
resulta imprescindível apresentar através de alguns dados significativos. A partir deles, a intenção aqui é contextualizar a situação social em que vivem os jovens entre 15 e 24 anos de idade, atendendo indicadores acerca das unidades domiciliares, do rendimento escolar e da violência (em referência aos jovens que se encontram cumprindo medida socioeducativa na FASE). Os dados apresentados não pretendem reduzir a multiplicidade de variáveis existentes na relação entre juventude e violência e, muito menos, esgotar a temática que vincula estas duas questões. Simplesmente, foram considerados de interesse para um dos argumentos centrais: que uma política para a juventude em situação de vulnerabilidade social deve focalizar-se em fomentar o "capital social" e, conjuntamente, a aqui denominada "cultura digital", e isto se vincula com certo diagnóstico sobre a família, a escola e a violência.

Segundo dados do IBGE de 2010, a população de Porto Alegre é de 1.409.351 habitantes, sendo a população jovem (entre os 15 e os 24 anos) 221.357 pessoas (15,7 \% do total).

\section{Tabela 1}

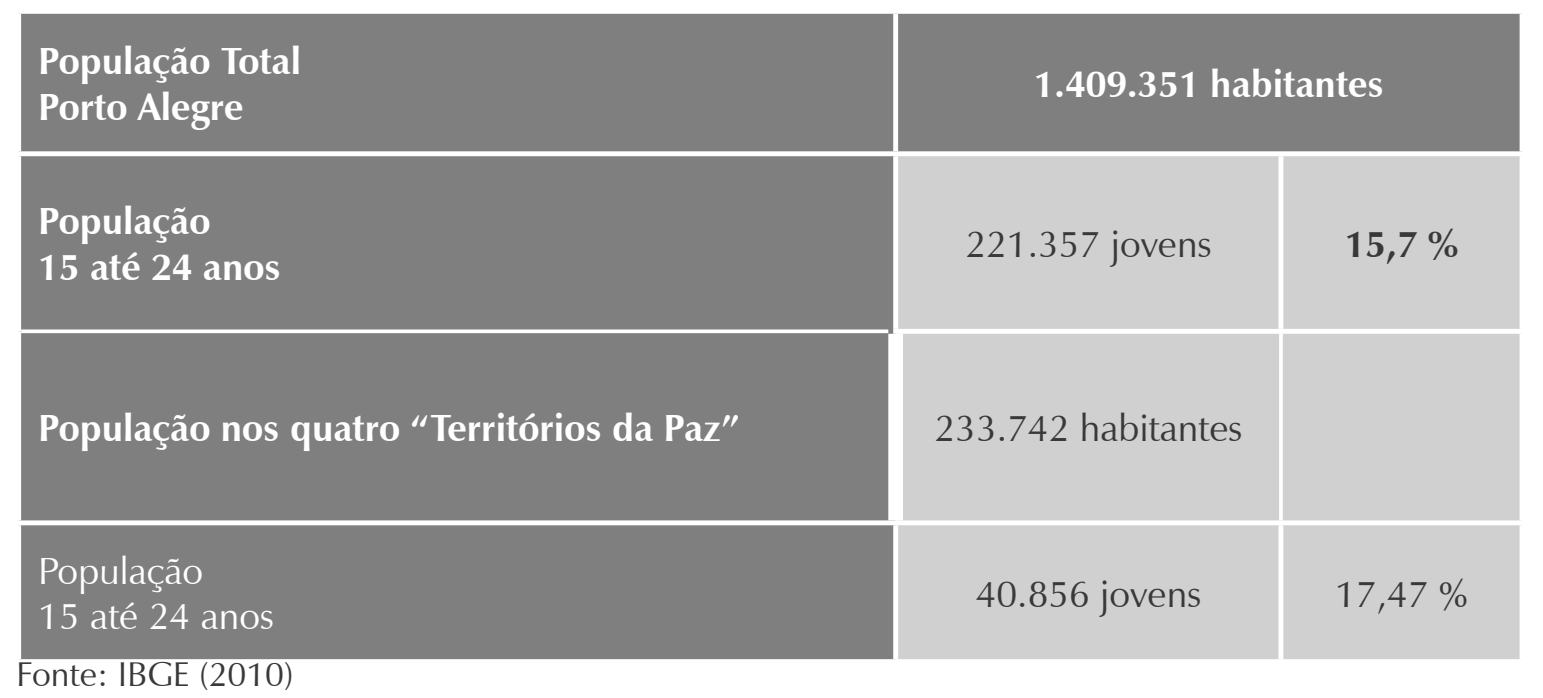


Desta população total, 233.742 pessoas moram nos quatro bairros estudados, e 40.856 pessoas têm entre 15 e 24 anos. Assim, a população jovem representa 17,47 \% (média algo superior à geral de Porto Alegre) (ver Tabela 1.). Em definitivo, faz-se referência aqui a uma população de algo mais de 40 mil jovens, cuja maioria, conforme constatado, é do sexo feminino. Por outro lado, ao atender à variável "cor ou raça", de grande importância para melhor compreender essa população, pode-se perceber que a diferença entre população "branca" e "afrodescendente" (junção de "pretos" e "pardos") é muito pequena, permitindo considerar que se está perante bairros de Porto Alegre com significativo contingente de população "afrodescendente" (ver Gráfico 1). Isso, mais do que um dado relevante, torna-se uma fonte de caracterização dos bairros, a qual permite entender dinâmicas excludentes que também assumem conotação étnico-racial. Dos quatro bairros, Restinga apresenta a maior porcentagem de população afrodescendente: 41,6 \%. Nos outros três bairros, as porcentagens são as seguintes: Santa Teresa, 33 \%; Lomba do Pinheiro, $32,2 \%$, e Rubem Berta, 29,3\%. Observando-se que a porcentagem da população afrodescendente de Porto Alegre é de 20,25 \%, pode-se deduzir que existe uma alta concentração dessa população nos quatro bairros, duplicando, como no caso de Restinga, a média da cidade. 
Gráfico 1. População residente / Cor ou Raça / Idade - Restinga - 2010

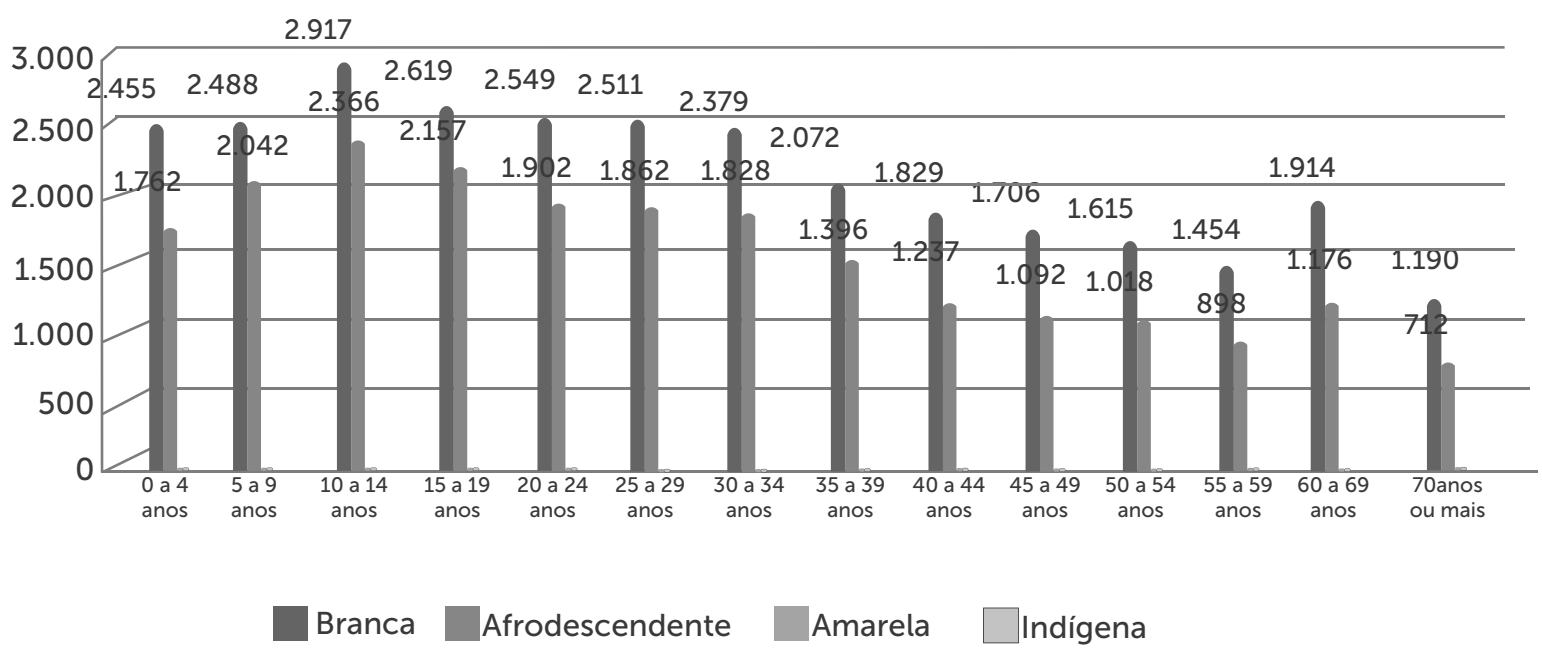

Fonte: IBGE (2010)

Conforme o Gráfico 1, os jovens afrodescendentes entre 15 e 19 anos do bairro Restinga representam 45\%, e os de 20 a 24 anos, $42,7 \%$ do total de jovens. Quer dizer, praticamente metade da população jovem identificou-se como "preta" ou "parda", no Censo de 2010 do IBGE. Por outro lado, observa-se uma numerosa população jovem, algo que se reitera nos outros três bairros pesquisados.

A essa caracterização, soma-se um dado muito relevante para compreender a forma dos laços de sociabilidade dos jovens e o "modelo de família" com o qual desenham processos socializadores. Resulta interessante prestar atenção à característica dos "lares"; sendo, nesta ocasião, o bairro Rubem Berta o exemplo a ser analisado. O cruzamento entre a característica "unidades domésticas" com o "sexo da pessoa responsável pelo domicílio" (ver Tabela 2) revela um elemento por demais importante: que a maioria dos "domicílios particulares permanentes" (51,17 \%) 
é "chefiada" por uma mulher. Isso é de grande relevância analítica, na medida em que advertimos o papel significativo que as mulheres têm na manutenção dos lares e na própria educação dos filhos e filhas. Essa tendência de conversão do papel da mulher (para provedora praticamente única da família) nos setores sociais mais vulneráveis, embora mantenha alguns pontos em comum com aquelas mulheres dos setores médios e altos (inserção no mercado de trabalho na busca de autonomia e realização profissional e pessoal), deve-se entender como estritamente econômico, dedicando-se, inclusive, a atividades de baixa qualificação, em precárias condições laborais e com baixas remunerações. Muitas vezes, as rupturas familiares devidas, em parte, à desocupação masculina, e a necessidade de a mulher constituir-se em provedora do "lar", refletem a alta quantidade de famílias "chefiadas" por mulheres, como se evidencia no número de "unidades domesticas unipessoais" sob a responsabilidade de mulheres (2,476, enquanto são 1.835 homens na mesma situação).

Outro fenômeno próprio dos setores sociais vulneráveis é a conformação de "famílias estendidas", em que, além de ambos cônjuges (ou no caso aqui analisado, o bairro Rubem Berta, com clara maioria de mulheres como responsáveis), também convivem outros familiares, em geral a mãe/avó ou irmãs que podem contribuir nas tarefas domésticas e cuidar das crianças enquanto a "chefa da família" está no trabalho. No bairro Rubem Berta, são 3.120 "unidades estendidas" sob a responsabilidade de mulheres - a maioria, em comparação com as 1.993 chefiadas por homens. Essas "famílias estendidas" estão, em geral, sob a responsabilidade de "mulheres-mães" de um ou mais filhos menores de 18 anos, que frequentarão os estabelecimentos educativos em determinados horários do dia e, no restante, ficarão eventualmente "ociosos" até o retorno da mãe do trabalho. 
Ao parecer, assiste-se a uma "feminização" crescente da responsabilidade familiar, denotando um verdadeiro impacto nas dinâmicas familiares, já que se apresenta necessário afrontar o cuidado dos filhos menores e, no caso de adolescentes, a supervisão de suas atividades fora do lar, nos estudos, na limpeza, no cuidado do lar e da roupa, da realização das refeições, etc. Algumas pesquisas (Nirenberg, 2006, pp.101-103) apontam que este quadro dos novos lares nos setores mais vulneráveis tem conduzido a dois fenômenos: ao ingresso cedo no mercado de trabalho (muitas vezes informal) de muitos jovens (aumentando a autonomia relativa), e ao "abandono escolar", resultante do baixo rendimento e da repetência.

Tabela 2. Domicílios particulares / Espécie de un. doméstica / Pessoa responsável / Sexo

\begin{tabular}{|c|c|c|c|}
\hline \multicolumn{4}{|c|}{ Bairro = Rubem Berta - Porto Alegre - RS } \\
\hline \multicolumn{4}{|c|}{ Ano $=2010$} \\
\hline $\begin{array}{l}\text { Espécie de } \\
\text { unidade } \\
\text { doméstica }\end{array}$ & $\begin{array}{l}\text { Sexo da pessoa } \\
\text { responsável pelo } \\
\text { domicílio }\end{array}$ & $\begin{array}{c}\text { Domicílios } \\
\text { particulares permanen- } \\
\text { tes (Unidades) }\end{array}$ & $\begin{array}{l}\text { Domicílios } \\
\text { particulares perma- } \\
\text { nentes (Percentual) }\end{array}$ \\
\hline \multirow[t]{2}{*}{ Total } & Homens & 14.037 & 48,83 \\
\hline & Mulheres & 14.710 & 51,17 \\
\hline \multirow[t]{2}{*}{ Unipessoal } & Homens & 1.835 & 6,38 \\
\hline & Mulheres & 2.476 & 8,61 \\
\hline \multirow[t]{2}{*}{ Nuclear } & Homens & 10.044 & 34,94 \\
\hline & Mulheres & 8.895 & 30,94 \\
\hline \multirow[t]{2}{*}{ Estendida } & Homens & 1.993 & 6,93 \\
\hline & Mulheres & 3.120 & 10,85 \\
\hline \multirow[t]{2}{*}{ Composta } & Homens & 165 & 0,57 \\
\hline & Mulheres & 219 & 0,76 \\
\hline
\end{tabular}

Fonte: IBGE (2010) 
A propósito, na Tabela 3, evidencia-se a taxa de distorção ou defasagem escolar, considerando, neste caso, os colégios públicos de Porto Alegre e os colégios públicos dos bairros Restinga, Lomba do Pinheiro, Rubem Berta e Santa Teresa. Evidentemente, não se pode, precipitadamente, deduzir que as altas taxas se relacionam com a estrutura familiar apontada anteriormente. Não se pode antecipar que o suposto "fracasso escolar" se deva à necessária relação com a "feminização" da chefia dos lares. De todas as maneiras, os dados podem, sim, contribuir a dilucidar como o "universo juvenil", nos lugares pesquisados, revela dificuldades no desempenho escolar em determinados momentos da construção subjetiva da personalidade e com certo vínculo com a trajetória familiar.

Como se pode perceber, é na $6^{\circ}$ série, ou $7^{\circ}$ ano do ensino fundamental, o "momento crítico" da defasagem escolar. Santa Teresa revela a taxa mais alta, com 62,36 \% dos alunos, enquanto Restinga a de menor representatividade. No entanto, em todos os bairros, incluindo a média de Porto Alegre, é neste estágio da vida escolar onde se observa o acumulo de situações adversas na passagem pelo sistema educativo. Previsivelmente, na $6^{\circ}$ série $/ 7^{\circ}$ ano, o jovem deveria ter aproximadamente 12 anos; mas se a defasagem se produz neste momento, está-se perante jovens que devem atingir nesse estágio escolar entre 14 a 16 anos. 
Tabela 3. Taxa Distorção / Defasagem Escolar - Colégios Públicos

\begin{tabular}{c|c|c|c|c|c}
\hline & $\begin{array}{c}\text { Porto } \\
\text { Alegre }\end{array}$ & $\begin{array}{c}\text { Rubem } \\
\text { Berta }\end{array}$ & $\begin{array}{c}\text { Santa } \\
\text { Teresa }\end{array}$ & $\begin{array}{c}\text { Lomba do } \\
\text { Pinheiro }\end{array}$ & Restinga \\
\hline 5a Série/ 60 Ano & 39,7 & 35,96 & 49,25 & 35,55 & 36,5 \\
\hline 6a Série/ 7o Ano & 46,1 & 43,27 & 62,36 & 40,48 & 41,2 \\
\hline 7a Série/ 8o Ano & 37,3 & 34,28 & 51,1 & 34,13 & 37,87 \\
\hline 8ª Série/ 9o Ano & 33,1 & 28,42 & 46,96 & 32,42 & 26,51 \\
\hline Ensino médio/ Total & 61,9 & 66,8 & 55,6 & s/d & 50,8 \\
\hline
\end{tabular}

Fonte: Instituto Nacional de Estudos e Pesquisas Educacionais - INEP, 2012

A repetência e/ou abandono são o sintoma explicativo para esse fenômeno, que tende $\mathrm{a}$ ir decrescendo à medida que se progride de séries no ensino fundamental. Outros estudos revelam que, justamente aos 14 e 15 anos de idade muitos jovens interpretam a repetência como "fracasso", abandonando, estrategicamente, o sistema educativo, para assim transitar para uma nova virada na construção da sua subjetividade ( $\mathrm{Ni}$ renberg, 2006). Não é casualidade, inclusive, que muitos desses jovens passaram a desempenhar trabalhos informais ou "bicos", ingressando no mundo do trabalho cedo. Esse diagnóstico permite compreender como, em situação de vulnerabilidade, muitos terminam sendo vítimas de uma reprodução das desigualdades, que se faz mediante o escasso ou nulo "capital cultural", decorrente de uma estrutura familiar e rede de relações (capital social) pouco propícias para o seu acúmulo. Em definitivo: à ausência de "capital cultural" no seio do lar e dos seus vínculos sociais imediatos, soma-se a saída de um sistema educativo que pouco teve para Ihe oferecer como saída prática da sua situação de vulnerabilidade.

Esse diagnóstico se relaciona, em parte, com o panorama da escolaridade dos jovens que cumprem medidas socioeducativas na FASE (Fundação de Atendimento Socioeducativo). Na Tabela 4, observa-se a escolaridade dos 450 jovens registrados até março de 2013, constatando- 
-se que a maioria, no momento do seu ingresso, tinha cursado a $5^{\circ}$ série (128) e a $6^{\circ}$ série (101). Poder-se-ia afirmar, por conseguinte, que exista uma estreita relação entre o ingresso na "vida delitiva" e o abandono escolar, concomitante à defasagem e a distorção escolar? Em certo sentido, pode-se admitir que tal fenômeno não seja uma simples casualidade. Por exemplo, em pesquisas desenvolvidas com jovens negros que estavam na FASE de Porto Alegre no ano de 2010, constatou-se que tinham sérios problemas de desistência ou abandono dos estudos aproximadamente aos 14 anos de idade ${ }^{5}$. Logo da saída do sistema educativo, o mercado laboral informal ou precário e, em alguns outros casos, o delito de pequeno porte (furto, por exemplo) têm sido as estratégias elaboradas para dar sequência às trajetórias das suas vidas.

\footnotetext{
${ }^{5}$ Com referência à pesquisa intitulada "Violência urbana e situações de conflito Uma análise sobre jovens negros na Região Metropolitana de Porto Alegre - RMPA" (Auxilio Bolsa de Produtividade - CNPq), sob coordenação dos autores.
} 
Tabela 4. Escolaridade da população atendida pela FASE-RS - 03/2013

\begin{tabular}{|c|c|c|c|c|c|c|c|c|}
\hline & $\begin{array}{l}\tilde{U} \\
\vdots\end{array}$ & $\begin{array}{l}u \\
\frac{u}{u} \\
\tilde{u}\end{array}$ & Uु & $\begin{array}{l}\bar{\delta} \\
0 \\
\Sigma \\
w \\
\tilde{s}\end{array}$ & $\begin{array}{l}\bar{z} \\
0 \\
\vdots \\
w \\
\tilde{u}\end{array}$ & 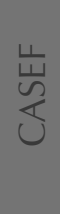 & 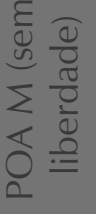 & $\stackrel{\vec{E}}{\stackrel{E}{0}}$ \\
\hline $1 \underline{a}$ & 2 & & & 2 & 1 & & & 5 \\
\hline $2^{\mathrm{a}}$ & 1 & 1 & 1 & 2 & 4 & & & 9 \\
\hline 3 & 1 & 2 & 3 & 5 & 6 & 1 & 1 & 19 \\
\hline $4^{\mathrm{a}}$ & 5 & 4 & 9 & 13 & 15 & 2 & 2 & 50 \\
\hline $5^{\underline{a}}$ & 24 & 7 & 36 & 22 & 34 & 3 & 2 & 128 \\
\hline $6^{\mathrm{a}}$ & 23 & 13 & 11 & 16 & 30 & 8 & & 101 \\
\hline $7 \underline{a}$ & 14 & 5 & 10 & 9 & 17 & 4 & & 59 \\
\hline $8^{\underline{a}}$ & 12 & 6 & 5 & 2 & 5 & & 1 & 31 \\
\hline 10 ano & 9 & 2 & 3 & 6 & 1 & 1 & 1 & 23 \\
\hline 20 ano & & 3 & 1 & 1 & 1 & & & 6 \\
\hline \multicolumn{9}{|l|}{30 ano } \\
\hline Não Informa & 2 & 4 & & 13 & & & & 19 \\
\hline Total & 93 & 47 & 79 & 91 & 114 & 19 & 7 & 450 \\
\hline
\end{tabular}

Fonte: Assessoria de Informação e Gestão - FASE-R

O que se pode deduzir a partir dos dados acerca da distorção ou defasagem escolar e dos relacionados à escolaridade dos jovens atendidos pela FASE é que uma faixa etária "crítica" no desenvolvimento dos itinerários juvenis se concentra entre os 14 e 15 anos. Embora isso se manifeste com clareza, bom é considerar que um "capital social perverso" (originado de práticas ilegais e delitivas) tem sido uma fonte de recursos e marco de referência importante para lidar com as adversidades cotidianas (Míguez, 2008). O jovem que ingressa na FASE pode carecer de "capital cultural" e de uma rede de relações sociais que alavanquem um projeto de vida "possível de ser vivido", mas isso não quer dizer que 
careçam, totalmente, de "capital social", já que têm conseguido mobilizar, em benefício próprio, "recursos associativos" que possibilitam acessar redes sociais específicas. E que tipo de redes sociais seria esse? A associatividade desses jovens cumprindo medida socioeducativa não se esgota no vínculo que sugere o "mundo do tráfico" e o seu processo de construção subjetiva que se inicia desde criança oficiando, por exemplo, de "office boy" do tráfico em troca de 10 reais. Estatisticamente, é o roubo o delito majoritariamente cometido por jovens, embora se suspeite que essa prática se vincule ao "tráfico de drogas" (ver Tabela 5).

Tabela 5. Tipos de Atos Infracionais - FASE-RS - 03/2013

\begin{tabular}{|c|c|c|c|c|c|c|c|c|}
\hline & 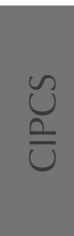 & 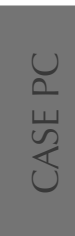 & $\vec{v}$ & 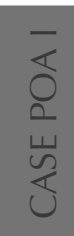 & 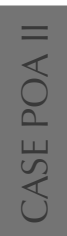 & 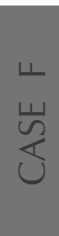 & 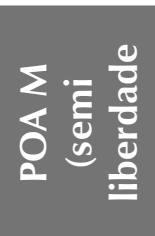 & $\frac{\frac{1}{6}}{6}$ \\
\hline Roubo & 41 & 11 & 29 & 33 & 66 & 2 & 1 & $\begin{array}{c}183 \\
(40,6 \%)\end{array}$ \\
\hline Tráfico de entorpecentes & 31 & 7 & 21 & 19 & 18 & 7 & 3 & $\begin{array}{c}106 \\
(23,5 \%)\end{array}$ \\
\hline Homicídio & 2 & 18 & 19 & 9 & 13 & 2 & 2 & 65 \\
\hline Tentativa de Homicídio & 2 & 1 & 1 & 6 & & 1 & & 11 \\
\hline Latrocínio & 4 & & 4 & 5 & 8 & 4 & & 25 \\
\hline Estupro & & & & 1 & & & & 1 \\
\hline Lesões Corporais & & & 1 & & 1 & & & 2 \\
\hline Tentativa de Latrocínio & & & & 4 & & 1 & & 5 \\
\hline Tentativa de Roubo & & & & 1 & & & & 1 \\
\hline Outros & & & & & & & & 50 \\
\hline Total Geral & & & & & & & & 450 \\
\hline
\end{tabular}

Fonte: Assessoria de Informação e Gestão - FASE-RS 
No entanto, são modalidades diferentes à hora de explicar dentro da FASE uma situação social vivida. O roubo pode ser considerado uma prática delitiva que se associa a "preencher" certas lacunas materiais e simbólicas no processo adolescente e juvenil, e isso pode, ou não, vincular-se com o "tráfico". Não obstante, aqui interessa considerar que, tanto para o roubo como para o "tráfico de entorpecentes" (quase o $64 \%$ dos delitos dos jovens da FASE), o jovem precisou, previamente, ter construído certo "capital social", algo que está em jogo, inclusive, quando a vida cotidiana passa a fazer parte de uma dinâmica sob a disciplina da medida socioeducativa.

A Tabela 6 proporciona dados acerca da quantidade de jovens atendidos pela FASE e cujo "bairro de origem" é algum dos quatro bairros estudados. De um total de 278 jovens de Porto Alegre, 87 são residentes desses bairros; quer dizer, $31 \%$ do total. Restinga representa o maior número de jovens (38), sendo 13,6 \% do total. Assim, é possível considerar que esse $31 \%$ do total representa uma taxa alta de jovens em medida socioeducativa, se comparada aos outros bairros de Porto Alegre? Vejamos: segundo dados de 2010 do IBGE, aproximadamente 98.000 jovens de 15 a 18 anos residem em Porto Alegre. Desses, residem nos bairros Restinga, Rubem Berta, Santa Teresa e Lomba do Pinheiro aproximadamente 17.000 jovens. Em definitivo, $17 \%$ do total de jovens porto-alegrenses nessa faixa etária moram nesses bairros. Portanto, uma avaliação estatística, meramente quantitativa, levaria a concluir que, proporcionalmente, os bairros estudados estão sobre representados na FASE (31\%). Evidentemente, se forem consideradas as características socioeconômicas dos bairros, o elevado porcentual de jovens na FASE não legitima afirmar que esses bairros são os que mais alimentam os índices de jovens que cometeram delitos na cidade. O que sim fica evidente é que a população jovem desses bairros participa notoriamente dessa estatística porque algumas 
causas socioeconômicas se traduzem num "capital social" criado em torno a estratégias delitivas conectadas ao universo juvenil. Ou seja: quando se percebe a existência de um "capital social", esse deriva de uma posição ligada à ilegalidade e a violência, capital que, certamente, uma clara minoria de jovens residentes nos bairros parece possuir.

Tabela 6. Total de jovens de POA / Bairro origem - "Territórios da Paz" - 03/2013

\begin{tabular}{|l|c|c|}
\hline PORTO ALEGRE & 278 & $100 \%$ \\
\hline Lomba do Pinheiro & 16 & $5,7 \%$ \\
\hline Restinga & 38 & $13,6 \%$ \\
\hline Santa Tereza & 23 & $8,2 \%$ \\
\hline Rubem Berta & 10 & $3,5 \%$ \\
\hline TOTAL BAIRROS & 87 & $31 \%$ \\
\hline
\end{tabular}

Fonte: Assessoria de Informação e Gestão - FASE-RS

Em definitivo, o que até aqui se tem considerado é o estabelecimento de uma relação importante entre a realidade juvenil e a violência, em determinadas situações de vulnerabilidade social, de certa maneira associadas à sociabilidade no âmbito da escola e da família. Obviamente, não se tratou de estabelecer determinismos nem componentes axiológicos fundamentadores de estatísticas e dados acerca de algumas características dos itinerários juvenis nos quatro bairros. Torna-se importante compreender que variáveis diversas podem estar conduzindo construções subjetivas sobre o "ser jovem", que se vinculam, a posteriori, com eventuais políticas para jovens. Eis aqui o ponto em que, a continuação, e de maneira breve, se procurará compreender o sentido desse tipo de políticas que têm privilegiado certos aspectos para a integração social e o desenvolvimento pessoal. 


\section{Políticas para jovens: perspectivas clássicas e novos horizontes}

Numa entrevista para a Revista Ñ do jornal argentino "Clarín", em 2 de agosto de 2013, Manuel Castells afirmou, dentre outras coisas, que la sociabilidad real se da hoy en Internet ${ }^{6}$. Castells considera que, enquanto o "tecido social" está fragmentado, supondo isolamento e problemas de circulação no meio urbano, bem como o usufruto seletivo dos espaços públicos das cidades, uma "cidade real" se reconstitui na Internet, uma espécie de laboratório de "agregação livre". Certamente, não se trata de negligenciar o espaço da rua como um espaço por demais importante da sociabilidade juvenil, mas o que interessa destacar é que Castells, direta ou indiretamente, sugere transmitir a real importância para a vida contemporânea que a Internet tem para o estabelecimento de redes de relações sociais que possam gerar o necessário "capital social" entre os jovens. Trata-se de atribuir à nova "cultura digital" um papel fundamental para os ganhos individuais e coletivos dos jovens nas sociedades da comunicação contemporâneas. Como bem afirma Castells, um sistema de comunicação livre e interativo agrupa as pessoas. Quanto mais usamos Internet, mais sociabilidade física temos.

Até o momento, praticamente a maior parte das iniciativas de elaboração e implementação de políticas para jovens não tem contemplado a importância dessa nova "cultura digital". Não se tem percebido sua ligação com a concreção de um "capital social" fundamental para o mundo de hoje. Elas claramente ainda se mantêm presas aos três paradigmas clássicos com os quais se pensa a relação juventude/sociedade: primeiramente, o "paradigma ligado à educação"; logo, o "paradigma ligado ao trabalho", e finalmente, o "paradigma ligado ao esporte e lazer". ${ }_{6}$ http://www.revistaenie.clarin.com/ideas/Manuel-Castells-sociabilidad-real-hoylnternet_0_
967703232.html (Acesso em 03/08/2013) 
O "paradigma ligado à educação" parte da premissa de que o aumento da escolaridade, com maior inserção na escola, está na base de uma política de inclusão social para jovens. Com certeza, isso tem enorme importância, mas parece negligenciar a escassa receptividade valorativa do sistema formal educativo como modelo de sociabilidade juvenil, bem como a crise de representação como espaço de construção identitária. Pode-se afirmar, inclusive, que isso se agrava quando se consideram jovens em situação de vulnerabilidade social, assistindo a escolas com escassa infraestrutura. Os índices de repetência e de defasagem (já analisados aqui) são testemunha disso. Em definitivo, não se pode continuar atribuindo à escola um papel central para uma política para jovens. Posteriormente, o "paradigma ligado ao trabalho", sob a ideia da importância de inserir aos jovens (assistindo-os o mais possível) no mercado de trabalho e conseguir a "empregabilidade sonhada", parece negligenciar, também, a passagem do "mundo fordista" e do homo faber para o "mundo digital" e o "homem digital", do trabalho manual (antigo atribuidor de reconhecimento intersubjetivo) para o trabalho intelectual, do típico mundo informacional e digital contemporâneo. Sendo assim, iniciativas de "profissionalização" com cursos técnicos para o ingresso em empregos de "secundária importância" estratégica para o mundo atual, submete os jovens dos bairros mais vulneráveis a darem sequência às desigualdades no acesso ao conhecimento valorado do mundo de hoje. Por último, o "paradigma ligado ao esporte e lazer" também merece uma reflexão crítica. Admite-se, obviamente, que as atividades esportivas entre os jovens contribuem ao aspecto lúdico e ao incentivo das práticas coletivas e colaborativas, ajudando na inserção social e possibilitando a destreza e habilidade motora em momentos fundamentais na formação de um jovem. Não obstante, trata-se de uma preeminência disciplinar do corpo do jovem sob o discurso de desenvolver capacidades próprias do homo 
faber, ampliando, comprovadamente, dinâmicas excludentes sobre as "políticas do corpo" na juventude. Aqui, ao corpo se Ihe atribui capacidade motora estritamente ligada a um mundo do trabalho que parece demandar "corpos coletivos", colaboracionismo e uma competitividade física e mecânica.

Acredita-se, aqui, que uma política para jovens deveria assumir a importância valorativa da "cultura digital" e do manejo, por jovens em situação de desigualdade material e simbólica, da "linguagem" que hoje atribui maior inserção social, econômica e política. Tudo indica que a maior carência nos jovens dos bairros estudados é de um "capital social" consolidado em rede de relações que lhes permita sair de determinadas situações adversas e, nisso, a "cultura digital" materializa o seu potencial.

No excelente documento "Reflexões sobre a Política Nacional de Juventude - 2003-2010" (Brasil, 2011) elaborado pelo Conselho Nacional da Juventude, pode-se perceber como as políticas implementadas (certamente uma grande quantidade) têm privilegiado aqueles aspectos ou "paradigmas" para o desenvolvimento de políticas para jovens, com algumas variações interessantes: soma-se o tema da cultura e da comunicação, da segurança ("vida segura") e do meio ambiente, bem como a dimensão da participação juvenil. Sem dúvida, trata-se de um documento muito interessante, em que se mencionam todas as ações governamentais sobre políticas para juventude.

No entanto, e sem deixar de reconhecer a importância que podem exercer políticas ancoradas nesses paradigmas, acredita-se, aqui, que uma política de/para jovens deve assumir a importância valorativa da "cultura digital" e do seu potencial de estruturar redes de sociabilidades mais amplas, algo praticamente inexistente no documento. A "linguagem" que hoje pode contribuir a atribuir maior inserção social, econômica e política a jovens em situação de desigualdade material e simbólica é, sem 
dúvida, aquela ligada ao mundo dos avanços tecnológicos na informação e comunicação, e é nesse "espaço" que se devem procurar maiores investimentos e esforços.

Existem, internacionalmente, alguns casos emblemáticos sobre o êxito da aplicação de uma nova maneira de pensar uma política para jovens. A experiência a que aqui faz-se menção está ancorada num novo paradigma, o denominado "paradigma de intervenção urbana". Este caracteriza-se por uma ação pública, política e de base sociocultural que procura "incidir" no ambiente urbano e social de uma determinada região da cidade, de um bairro ou comunidade, a partir de uma "ação de intervenção arquitetônica" com edifícios modernos e esteticamente atrativos, que "quebram" o ritmo tradicional do espaço das sociabilidades violentas e fragmentadas, principalmente entre os mais jovens. Assim, na cidade de Medellín, na Colômbia, a partir do ano 2007, e por iniciativa do poder público, instalou-se o chamado "Parque Biblioteca España", no populoso bairro de Santo Domingo, como mostram as Imagens 1 a 4 . 


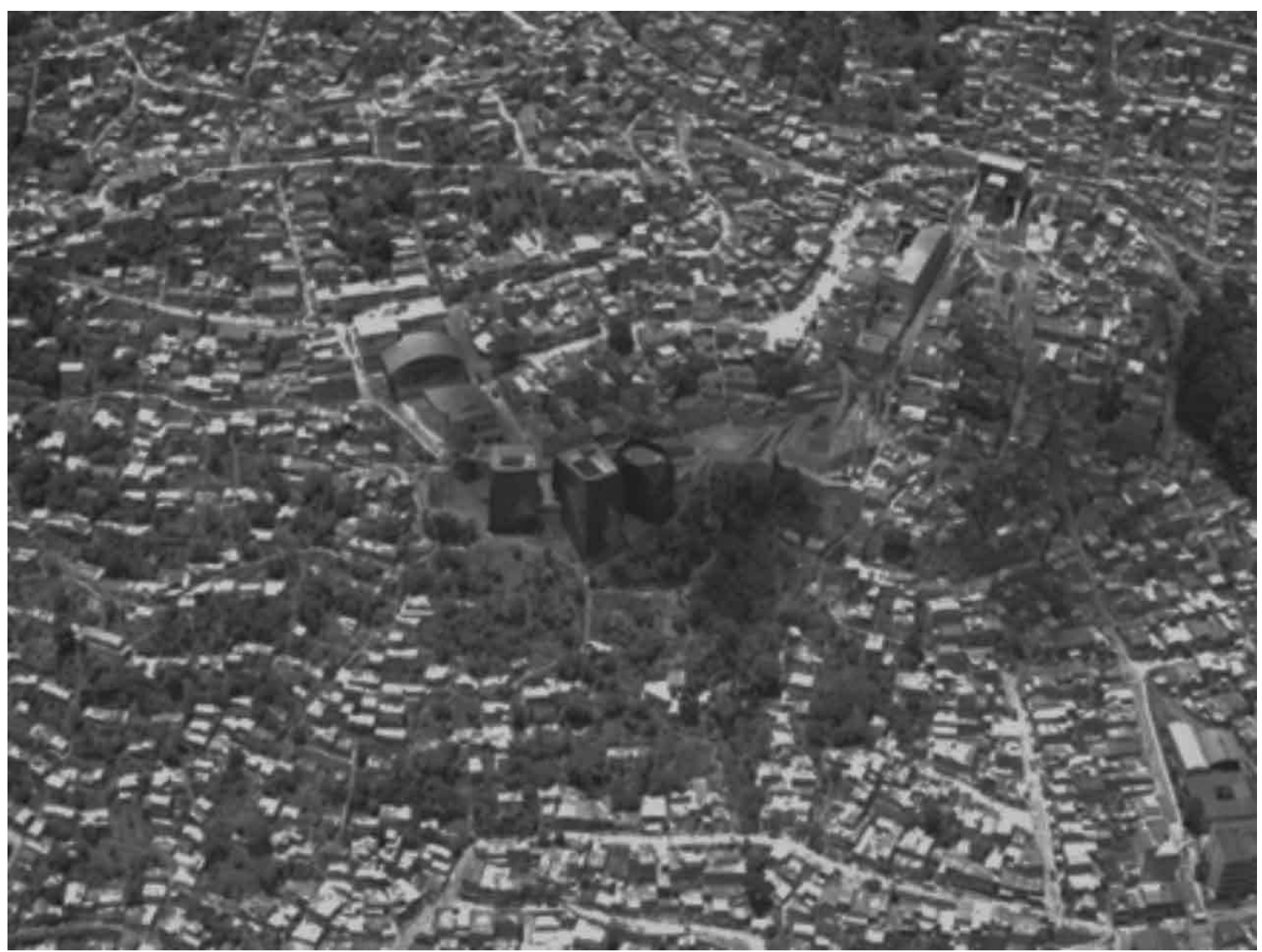

Imagem 1.Vista aérea do Parque Biblioteca España (ao centro) e do bairro Foto de (c) Carlos Tobon

Importante esclarecer que não se tratou de uma iniciativa pensada unicamente como uma política para a juventude, nem de instituições ou organismos dedicados a esse público. Foi sim uma política mais abrangente de inibição da violência na região, mas que teve entre a população jovem o seu objeto mais atingido. O Parque Biblioteca España seria o quarto Parque dos cinco propostos pelo governo da cidade, e trouxe uma enorme expectativa nos moradores do bairro e de toda a comunidade nacional da Colômbia. Como bem mencionam Vélez e Isaza (2011), este espaço no bairro é hoje muito valorizado pela maioria dos seus habitantes 
como uma possibilidade de acesso a livros, internet, recreação e como uma "nova imagem" perante a cidade.

O projeto urbanístico tornou-se, por conseguinte, dinamizador de processos de inclusão e desenvolvimento para os jovens desde a cultura, como alternativa à violência e à indiferença que impera na relação entre juventude e "cultura digital". Devido, justamente, à sua localização estratégica e aos seus programas de educação, cultura e sociabilidade, tornou-se o principal referente da comunidade, bem como o incentivador de uma aproximação ao conhecimento, à informação, e à educação, como principal alternativa à "cultura da violência"7. Importante destacar que se tratou de um empreendimento o qual, desde sua fase de diagnóstico, planejamento e execução, teve a participação dos habitantes do bairro, acompanhando as equipes técnicas, os trabalhadores sociais e os diferentes atores do setor público e de políticas para jovens, na realização das tarefas. Dessa maneira, elevou-se o nível de comprometimento e pertencimento em relação ao espaço do bairro, questão fundamental para o êxito dessa "intervenção urbana".

\footnotetext{
7 Para mais detalhes sobre o "Parque Biblioteca España", acessar: http://www.reddebibliotecas. org.co/sistemabibliotecas/Paginas/parque_biblioteca_espana.aspx e http://www.parquebibliotecaespana.blogspot.com.br/
} 


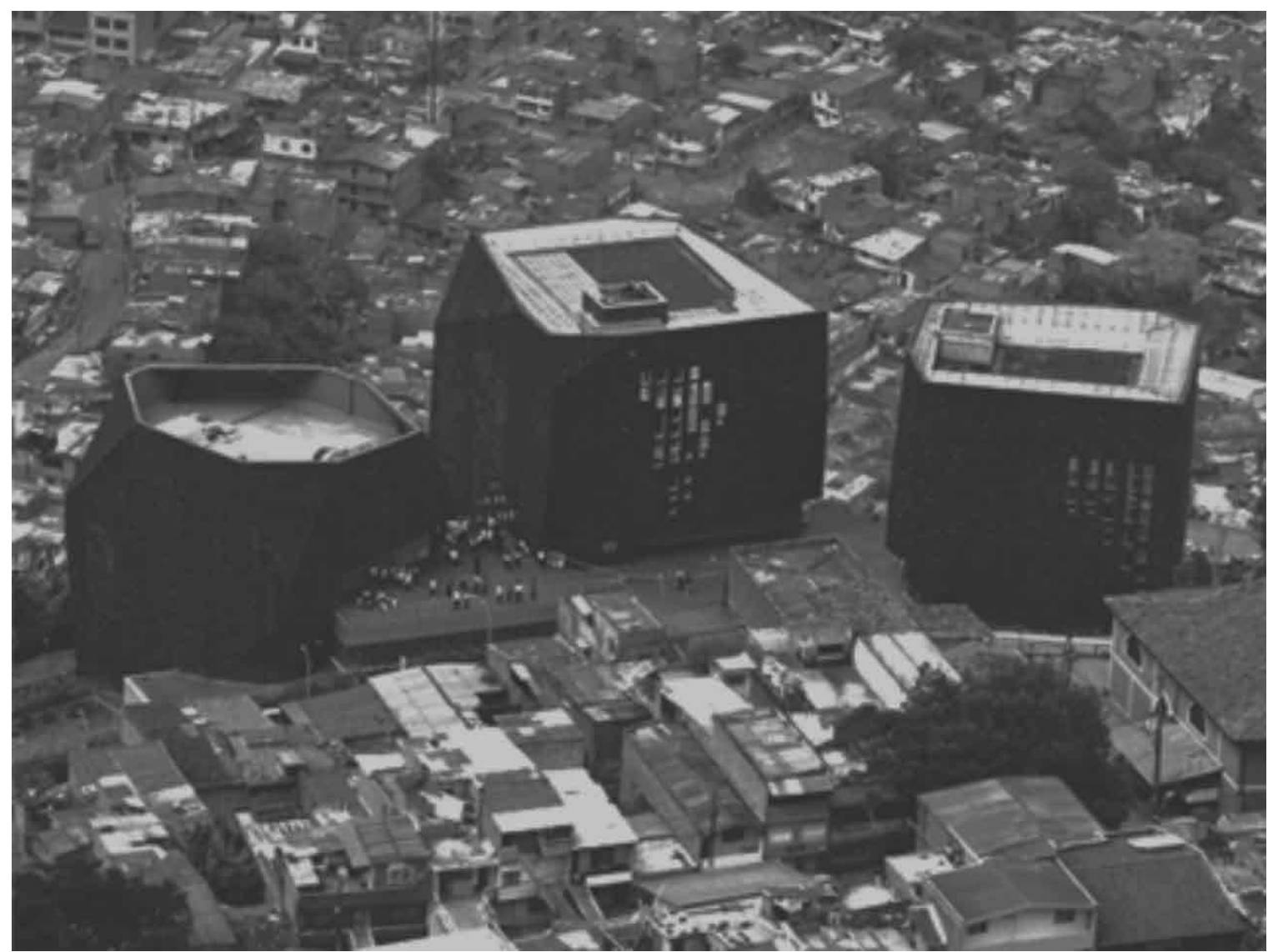

Imagem 2. Vista aérea dos três prédios que compõem o Parque Biblioteca España Fonte: Google Imagens

O "paradigma da intervenção urbana", sob o qual se construíram os "Parques bibliotecas", refere-se a uma proposta urbanística de intervenção no ambiente formada por edificações de arquitetura moderna e esteticamente "chamativa", com amplos espaços circundantes de uso público, "verde", decorativo, para o trânsito de pedestres. O eixo da edificação está dotado de biblioteca com equipamento de alta tecnologia computacional. São, na realidade, "Centros Culturais" para o desenvolvimento social, que fomentam o "encontro cidadão", as atividades educativas e lúdicas, a construção de "coletivos", a aproximação com a cultura digital. Também são espaços para a prestação de serviços culturais, permitindo a criação cultural e o fortalecimento das organizações de bairro existentes. 
As ideias essenciais do "projeto" consistem em coparticipar da transformação da "mentalidade das comunidades" menos favorecidas, melhorar o entorno físico e cultural, servir de estímulo e motor para sua renovação e mudança, favorecer seu "orgulho cidadão" e "sentido de pertença" e, obviamente, oferecer alternativas de alta tecnologia para a diversão, a conectividade, educação e cultura. Por sua moderna estética e atração, o "Parque Biblioteca" converteu-se em referente urbano e arquitetônico, sob o lema: "o melhor para os que mais necessitam", proporcionando ambientes interiores para o estudo e a cultura, e espaços públicos exteriores para a interação comunitária, as atividades lúdicas e o lazer.

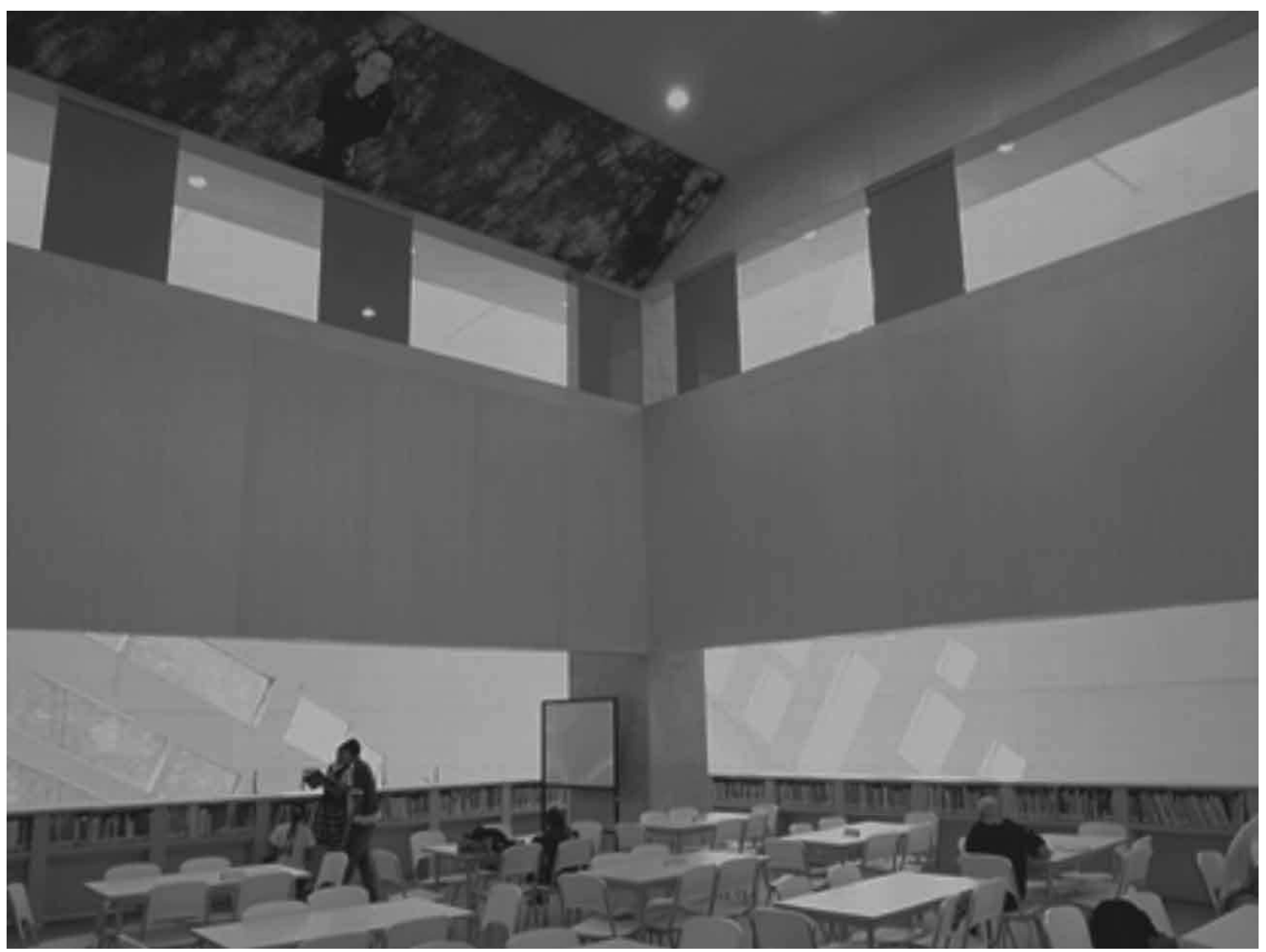

Imagem 3. Vista interior do Parque Biblioteca España

Foto de (C) Diana Moreno 


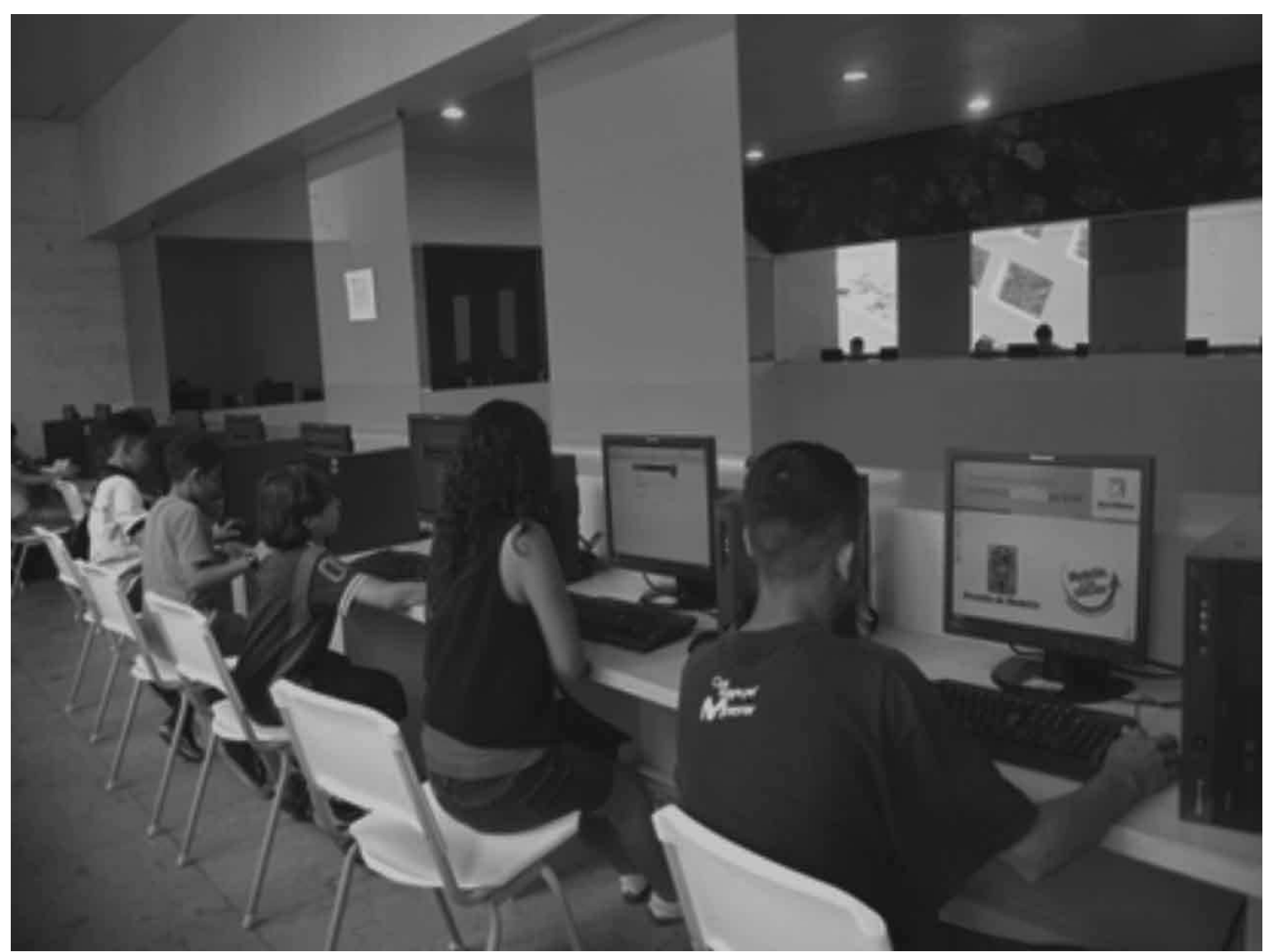

Imagem 4. Jovens e crianças usando os computadores do Parque Biblioteca España Foto de (C) Diana Moreno

Em termos gerais, através desse trabalho, percebeu-se como os jovens demonstram ter uma sociabilidade muito limitada e fragmentada. A incapacidade de circulação pela cidade, a "âncora de sociabilidade" a que o bairro, perversamente, submete, impossibilitando o movimento pela cidade e a ampliação de sociabilidades territorialmente demarcadas, parece ser um dos principais traços das sociabilidades jovens nesses bairros de Porto Alegre. As únicas fontes claras de criação de redes são o colégio e o bairro e, em menor medida, a família. Se admitirmos que a sociabilidade seja um princípio de abertura e de transcendência social, que permite conhecer e assimilar aquilo que é desconhecido, que não 
está ao alcance imediato, e se admitirmos, da mesma maneira, que aquilo que é próprio da sociabilidade é a capacidade de fundar vínculos além do contexto de identificação imediato e direto, esses jovens se apresentam muito enraizados numa espécie de "comunidade territorial" (e social) que não lhes permite resolver aqueles problemas da diferença e da alteridade através de redes mais amplas e eficientes.

As redes de relações em que esses jovens estão inseridos permitem uma comunicação entre os atores de "redes já estabelecidas", não existindo referências sobre processos de exploração ou de busca de outras redes, mas sim a consolidação de redes já predefinidas. E que redes seriam essas? Aquelas que podem permitir "proteção", o reduto que eventualmente torna menos angustioso o processo de contato com novos ambientes ou entornos que são desconhecidos e, por vezes, ameaçadores. Esse reduto, para alguns, pode ser a própria família, e, para outros. o "grupo de amigos". Para os menos favorecidos, uma rede de relações ligadas à cadeia do tráfico de drogas, o delito e a violência. Concretamente, esses vínculos que se criam com amigos do bairro ou da escola, ou estabelecidos nessas "redes da violência", apresentam-se bastante impregnados pela necessidade do "reconhecimento" em uma experiência de vida semelhante, em um mesmo sistema de valores, tornando a sociabilidade, assim, num "pequeno universo" que se pode governar sem necessidade e esforço de abertura e transcendência social.

Tudo indica que a maior carência nesses jovens é de "capital social", da capacidade para ingressar numa rede de relações sociais que thes permita sair de determinadas situações adversas. Acredita-se, então, que a "cultura digital" poderia materializar esse potencial agregador e de comunicação. Para finalizar, lembra-se o que se tem realizado em Medellín, na Colômbia: uma política de redução da violência que conseguiu reestabelecer laços sociais fragmentados pela sombra do narcotráfico. Os denomi- 
nados "Parques Bibliotecas", prédios esteticamente bonitos, iluminados, com computadores com acesso à Internet livre, software, livros, filmes e espaços para reuniões e estudo, converteram-se em centros comunitários onde a "cultura digital" era usufruída por jovens desde os 10 anos de idade. Uma série de depoimentos ${ }^{8}$ evidenciam as mudanças significativas na sociabilidade juvenil, sendo a de maior importância a possibilidade de desenvolver um "capital social" positivo, alimentado pelo conhecimento e a informação, a cultura e o incentivo à pesquisa no espaço da Internet.

Certamente, à "cultura digital" se deve somar a construção de uma cultura da paz, da convivência e do respeito por aquela população que

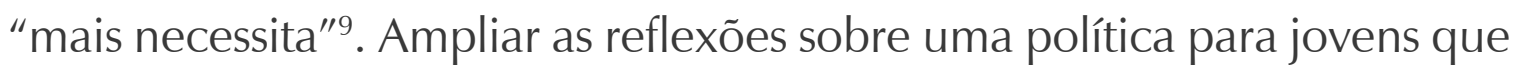
dialogue com os problemas urbanos e as carências diversas reais é o desafio contínuo, que não cessará, certamente, com a implementação de um novo "paradigma de intervenção urbana" para combater os problemas de violência entre a população jovem vulnerável. Entende-se, sim, que ele pode ser, no contexto atual, um importante começo, já impostergável, de políticas para/de jovens, que contemplem as novas "palavras chave" dos jovens contemporâneos: conectividade, circulação, contato, virtualidade, "linguagem digital" e expressividade.

\footnotetext{
8 Por exemplo, veja-se o seguinte em: "Parques Bibliotecas se fortalecem em Medellín", (2010) http://infosurhoy.com/cocoon/saii/xhtml/pt/features/saii/features/society/2010/03/25/ feature-02

9 Cf. "Informe Regional de Población en América Latina y el Caribe 2011: Invertir en juventud" da CEPAL (2011), o desenho do melhoramento das políticas de juventude se relaciona com: a) as políticas devem colocar no centro dos seus objetivos o desenvolvimento e fortalecimento das capacidades e a ampliação da estrutura de oportunidades dos jovens, e b) se tornam mais importantes que nunca medidas positivas para atender a heterogeneidade das exclusões que afetam os jovens.
} 
Carlos A. Gadea é professor e pesquisador do Programa de Pós-graduação em Ciências Sociais da Unisinos. São Leopoldo, Brasil. Co-Coordenador do Observatório Juvenil do Vale, Unisinos.

$\gg$ cgadea@unisinos.br

José Silon é Integrante do Observatório Juvenil do Vale, Unisinos. Doutorando do Programa de Pós-graduação em Ciências Sociais da Unisinos, Brasil

$\searrow$ silonf@hotmail.com

Fátima Sabrina da Rosa é Integrante do Observatório Juvenil do Vale, Unisinos. Doutoranda do Programa de Pós-graduação em Ciências Sociais da Unisinos, Brasil. $\searrow$ sabrinna.rosa@hotmail.com

Marcia da Silva Cezar é Integrante do Observatório Juvenil do Vale, Unisinos. Doutoranda do Programa de Pós-graduação em Ciências Sociais da Unisinos, Brasil

$\triangle$ marcia_cezar@unisinos.br

Hilário Dick é Co-Coordenador do Observatório Juvenil do Vale, Unisinos, Brasil $\searrow$ hiladick@gmail.com

\section{Referências}

1. ABRAMO, H. W.; BRANCO, P. P. M. (Orgs) Retratos da Juventude Brasileira análise de uma pesquisa nacional. Ed. Perseu Abramo, São Paulo. 2005.

2. ADORNO, S. O adolescente e as mudanças na criminalidade urbana. São Paulo em Perspectiva, v. 13, n. 4, pp. 62-74, São Paulo. 1999.

3. BRASIL. Reflexões sobre a Política Nacional de Juventude (2003-2010). Brasilia: Conselho Nacional da Juventude, 2011.

4. CASTELLS, M. La sociabilidad real se da hoy en Internet. Entrevista Manuel Castells. Revista Ñ. Clarín. 02 de ago de 2013. Disponível em: https://www.clarin. com/ideas/manuel-castells-sociabilidad-real-hoy-internet_0_SJ0QH5rswme.html. Acesso em 03.08.2013

5. CEPAL. Informe Regional de Población en América Latina y el Caribe: invertir en juventud. CEPAL, Fondo de Población de las Naciones Unidas, 2011. 
6. FEATHERSTONE, M. Cultura de consumo e pós-modernismo. São Paulo: Studio Nobel, 1995.

7. GADEA, C. A. Violence and Collective Conflict Experiences. Societies Without Borders, v. 5, n.1, University of North Carolina, USA, 2010

8. KOURY, M. G. P. Cultura da violência e o medo do outro: observações sobre medos, violência e juventude no Brasil atual. In: Revista de Antropologia Experimental, n. 4, Universidad de Jaén, España. 2004,

9. LE BON, G. Psicología de las multitudes. Buenos Aires: Albatros, 1952.

10. LIPOVETSKY, G. La era del vacío. Ensayo sobre el individualismo contemporâneo. Barcelona: Anagrama. 1994.-

11. MAFFESOLI, M. A contemplação do mundo. Porto Alegre: Artes e Ofícios, 1995.

12. MAFFESOLI, M. O tempo das tribos. O declínio do individualismo nas sociedades de massa. Rio de Janeiro: Forense Universitária, 1989.

13. MAGNANI, J. G. O circuito dos jovens urbanos. Tempo Social, v. 17, n. 2, São Paulo, 2005.

14. MARGULIS, M. (Ed.). La juventud es más que una palabra. Ensayos sobre cultura y juventud. Buenos Aires: Biblos, 2000.

15. MíGUEZ, D. Delito y cultura. Los códigos de la ilegalidade em la juventude marginal urbana. Buenos Aires: Ed. Biblos, 2008.

16. MORAES, P. R. B.de; SOUZA, M. G.de. Invisibilidade, preconceito e violência racial em Curitiba. Rev. Sociol. Polit., Curitiba, n. 13, p. 7-16, Nov.1999.

17. NIRENBERG, O. Participación de adolescentes en proyectos sociales. Aportes conceptuales y pautas para su evaluación. Buenos Aires: Paidós, 2006.

18. PNUD. Relatório de Desenvolvimento Humano: Racismo, Pobreza e Violência. PNUD, Brasilia, 2005.

19. SBP - SOCIEDADE BRASILEIRA DE PEDIATRIA. Guia de atuação frente a maus-tratos na infância e na adolescência. Rio de Janeiro: SBP/ Claves/ ENSPFiocruz/ MJ-SEDH, 2001.

20. SOARES, L. E. (org.) Violência e Política no Rio de Janeiro. Relume Dumará e ISER: Rio de Janeiro, 1996

21. TISSOT, S. A invenção de 'bairros problemáticos'. Le Monde DiplomatiqueBrasil. 1o outubro de 2007. Disponível em: http://diplomatique.org.br/a-invencao-de-bairros-problematicos-2/ 
22. VÉLEZ, M. E; ISAZA, C. Entre la planeación urbana, la apropiación del espacio y la participación ciudadana. Los pactos ciudadanos y el Parque Biblioteca de España de Santo Domingo Savio. Estudios Políticos, n. 39, p. 117-140, Medellín, 2011.

23. WACQUANT, L. Os condenados da cidade. Rio de Janeiro: Ed. Revan, 2005.

Recebido: 03.05.2016

Aceite final: 24.08 .2016 